\title{
DNAH9 wt Allele
}

National Cancer Institute

\section{Source}

National Cancer Institute. DNAH9 wt Allele. NCI Thesaurus. Code C150220.

Human DNAH9 wild-type allele is located in the vicinity of $17 \mathrm{p} 12$ and is approximately

$372 \mathrm{~kb}$ in length. This allele, which encodes dynein heavy chain 9, axonemal protein, plays a role in the regulation of the movement of cilia and flagella. 